\title{
Intake, gain and carcass traits of Hereford and Charolais bulls offered diets based on triticale, barley and grass silages
}

\author{
Arto Huuskonen ${ }^{1}$, Seija Jaakkola² and Katariina Manni ${ }^{3}$ \\ ${ }^{1}$ Natural Resources Institute Finland (Luke), Production Systems, Halolantie 31A, FI-71750 Maaninka, Finland \\ ${ }^{2}$ University of Helsinki, Department of Agricultural Sciences, P.O. Box 28, Fl-00014 University of Helsinki, Finland \\ ${ }^{3}$ Natural Resources Institute Finland (Luke), Production Systems, Tietotie 2C, FI-31600 Jokioinen, Finland \\ email: arto.huuskonen@luke.fi
}

\begin{abstract}
Total mixed rations (TMR) based on grass silage (GS), triticale silage (TS), mixture of GS and TS, barley silage (BS) and mixture of GS and BS were fed to fifty Hereford (HF) and fifty Charolais (CH) bulls. The proportion $\left(\mathrm{g} \mathrm{kg}^{-1} \mathrm{dry}\right.$ matter [DM]) of the silages in the TMRs were as follows: (1) GS (600); (2) TS (600); (3) GS (300) and TS (300); (4) BS (600); (5) GS (300) and BS (300). Concentrate proportion was $400 \mathrm{~g} \mathrm{~kg}^{-1} \mathrm{DM}$. According to feed analyses, the GS had 15 and $8 \%$ higher metabolizable energy (ME) concentration as well as 51 and $49 \%$ higher crude protein (CP) concentration compared to TS and BS, respectively. Average DM intake (DMI) on TS and BS containing diets was higher compared to GS as a sole forage $(p=0.001)$. Compared to the TS based rations the use of BS rations increased daily DMI by $5 \%(p<0.05)$. In CH bulls, DMI decreased $0.8 \mathrm{~kg} \mathrm{~d}^{-1}$ when GS partially replaced TS or BS while in HF bulls the use of silage mixtures slightly increased DMI $\left(0.23 \mathrm{~kg} \mathrm{~d}^{-1}\right)$. The live weight gain (LWG) and carcass gain of the $\mathrm{CH}$ bulls were 5 and $26 \%$ higher, respectively, compared to the HF bulls. Inclusion of GS in the diet increased LWG and carcass gain with TS but decreased them with BS (interaction $p<0.01$ ). The experiment demonstrated lower feeding value of TS compared to BS in the diet of the bulls. Whole crop silage based rations increased DMI compared to GS as a sole forage in the TMR. When GS partially replaced TS or BS, interactions in LWG and carcass gain results demonstrated higher feeding value for BS and lower for TS compared to GS. Feeding treatments had only minor effects on carcass traits of the bulls.
\end{abstract}

Key words: beef production, growth performance, Hordeum vulgare, Phleum pratense, whole crop silages, $X$ Triticosecale

\section{Introduction}

In Nordic countries most of the forages fed to growing and finishing cattle are traditionally based on ensiled mixtures of different grasses and red clover (Trifolium pratense) (Pesonen et al. 2014). Although timothy (Phleum pratense) and meadow fescue (Festuca pratensis) are the dominant forage plants in Finland, different whole crop silages may play an increasingly significant role in the future. Small grain cereal based whole crop silages provide an opportunity to improve efficiency of forage production for ruminants under Nordic conditions (Rustas 2009, Huuskonen and Joki-Tokola 2010, Huuskonen et al. 2016). High dry matter (DM) yields at a single harvest and the potential to reduce production costs have increased the interest in using whole crop silages in cattle feeding.

In Finland, barley (Hordeum vulgare) has been the dominant small grain species utilized for whole crop silage production, but oats (Avena sativa) and wheat (Triticum aestivum) are also used (Huuskonen et al. 2017). The digestibility of whole crop silages generally depends on the proportions of straw and grain and is typically lower than that of high quality grass silage (GS) but the lower digestibility is often compensated by higher DM intake (DMI) (Keady 2005, Keady et al. 2007). In a review of four experiments with finishing cattle Keady (2005) concluded that the inclusion of whole crop wheat silage in GS based diets increased forage intake by $1.4 \mathrm{~kg} \mathrm{DM} \mathrm{d}^{-1}$, but did not affect animal performance. On the contrary, Huuskonen (2013) reported no treatment differences in daily DMI when GS was completely replaced by whole crop barley silage.

Interest in triticale ( $X$ Triticosecale) cultivation has recently increased in Nordic countries because of climate change and longer growing seasons (Peltonen-Sainio et al. 2009). Triticale has been fed successfully to cattle as grain (Hill and Utley 1989, ZoBell et al. 1990) but less information is available on its use as whole crop silage, and the results have been partly contradictory. Similar intake, gain and feed efficiency were observed when barley silage (BS) and triticale silage (TS) were fed at relatively low levels (258-380 $\mathrm{g} \mathrm{kg}^{-1} \mathrm{DM}$ ) with barley grain to feedlot steers (ZoBell et al. 1992). Harper et al. (2017) demonstrated that in dairy cows DMI was not affected while milk yield decreased when TS replaced maize silage at the rate of $10 \%$ in the diet DM, while McCartney and Vaage (1994) reported that TS was less acceptable than barley or oat silages resulting in lower DMI and growth rate in growing beef heifers. 


\section{AGRICULTURAL AND FOOD SCIENCE}

A. Huuskonen et al. (2020) 29: 318-330

O'Kiely (2011) concluded that diets based on TS of relatively low grain proportion supported low performance rates by growing steers when compared to diets based on GS or maize silage or ad libitum concentrate.

In several growing cattle experiments GS has typically been completely replaced by whole crop silages, and no differences in DMI were observed when GS was replaced by TS (O'Kiely 2011) or BS (Huuskonen and Joki-Tokola 2010, Huuskonen 2013, Huuskonen et al. 2017). However, in a meta-analysis of dairy cow feeding experiments the maximum silage DMI was obtained when the proportion of the whole crop silage was 0.48 of total silage DM. Replacing primary growth GS with whole crop silage affected silage DMI quadratically so that the intake of the mixture of GS and whole crop silages was higher than the mean intake of either forage fed alone (Huhtanen et al. 2007). Nevertheless, it is not certain whether the same phenomenon will occur in growing cattle. Therefore, more research on mixtures of whole crop silage and GS is needed.

The objective of the present experiment was to study feed intake, gain and carcass traits of Hereford (HF) and Charolais $(\mathrm{CH})$ bulls offered total mixed rations (TMR) based on GS, TS, mixture of GS and TS, BS and mixture of GS and BS. Possible interactions between silage plant species and breed were also examined. Current breeds were chosen because they are common beef breeds used in Finland. It was hypothesized that: (1) whole crop silages and mixtures of whole crop silage and GS increase DMI, but do not affect gain or carcass traits compared to GS as a sole forage in the TMR; (2) the use of TS instead of BS decreases DMI and gain of the bulls; (3) partial replacement of TS or BS with GS improves DMI and gain; (4) the effects of GS inclusion in the diet are similar with TS and BS; and (5) there are no interactions between breed and feeding treatments on animal performance.

\section{Material and methods \\ Animals and housing}

A feeding experiment was carried out in the experimental cattle unit of Natural Resources Institute Finland (Luke) in Ruukki starting in February 2018 and ending in August 2018. The experiment was conducted using fifty purebred HF and fifty purebred CH bulls. All animals, with an initial live weight (LW) of $428( \pm 42.8)(\mathrm{HF})$ and 453 ( \pm 58.5 ) $(\mathrm{CH}) \mathrm{kg}$, were purchased from commercial herds. The HF bulls were from seven and the $\mathrm{CH}$ bulls from six different sires. There were five to nine HF bulls and five to ten $\mathrm{CH}$ bulls per sire in each five feeding treatment. The bulls were moved to the experimental cattle unit of Luke on average on seven months of age, three months before the start of the feeding experiment. During this pre-experimental period the bulls were adapted to housing conditions and GS plus barley grain based feeding. The bulls remained healthy throughout the pre-experimental period. At the start of the present feeding experiment HF and $\mathrm{CH}$ bulls were on average $309( \pm 16.1)$ and 311 ( \pm 15.9$)$ days old, respectively. Animals were managed according to the Finnish legislation regarding the use of animals in scientific experimentation.

The bulls were housed in an uninsulated barn in pens ( $10.0 \mathrm{~m} \times 5.0 \mathrm{~m} ; 5$ bulls in each pen), providing $10.0 \mathrm{~m}^{2}$ per bull. The rear half of the pen area was a peat-bedded lying area and the fore half was a feeding area with a solid concrete floor. A GrowSafe feed intake system (model 4000E; GrowSafe Systems Ltd., Airdrie, AB, Canada) was used to record individual daily feed intakes so that each pen contained two GrowSafe feeder nodes. The bulls had free access to water at all times during the whole feeding experiment.

\section{Feeding and experimental design}

At the beginning of the experiment, both $\mathrm{HF}$ and $\mathrm{CH}$ bulls were randomly allotted to pens which were randomly allotted to five feeding treatments so that each treatment included two HF pens and two CH pens (20 bulls per treatment). The five experimental diets included GS, TS or BS as sole forage or a mixture of TS or BS and GS (Table 1). The forage proportion ( $600 \mathrm{~g} \mathrm{~kg}^{-1} \mathrm{DM}$ ) and the proportions of rolled barley ( $\left.335 \mathrm{~g} \mathrm{~kg}^{-1} \mathrm{DM}\right)$, rapeseed meal (50 $\left.\mathrm{g} \mathrm{kg}^{-1} \mathrm{DM}\right)$ and mineral-vitamin mixture (15 $\left.\mathrm{g} \mathrm{kg}^{-1} \mathrm{DM}\right)$ were the same in each diet. The bulls were fed TMR ad libitum (proportionate refusals of 5\%). Rations were mixed in a mixer wagon (Trioliet, BW Oldenzaal, the Netherlands) once a day. Two CH bulls (one GS and one TS) were excluded from the study due to hoof problems and one HF bull (GS) due to pneumonia. There was no reason to suppose that the diets had caused these problems. The other 97 bulls remained healthy throughout the study. 


\section{AGRICULTURAL AND FOOD SCIENCE}

A. Huuskonen et al. (2020) 29: 318-330

Table 1. The proportion ( $\mathrm{g} \mathrm{kg}^{-1}$ dry matter) of the feeds in the experimental diets

\begin{tabular}{lccccc}
\hline Treatment & GS & TS & GSTS & BS & GSBS \\
\hline Grass silage & 600 & & 300 & & 300 \\
Triticale silage & & 600 & 300 & & \\
Barley silage & & & & 600 & 300 \\
Rolled barley grain & 335 & 335 & 335 & 335 & 335 \\
Rapeseed meal & 50 & 50 & 50 & 50 & 50 \\
Mineral-vitamin mixture & 15 & 15 & 15 & 15 & 15 \\
\hline
\end{tabular}

All experimental silages were produced at the experimental farm of Luke in Ruukki $\left(64^{\circ} 44^{\prime} \mathrm{N}, 25^{\circ} 15^{\prime} \mathrm{E}\right)$. The GS was a primary growth from a timothy (Phleum pratense, cv. Tenho, Boreal Plant Breeding Ltd., Jokioinen, Finland) sward, cut on 28 June 2017 by using a mower conditioner (Elho 280 Hydro Balance, Oy Elho Production Ab, Pännäinen, Finland), wilted for approximately 24 hours after cutting, and harvested using a precision-chop forage harvester (New Holland FX 60, CNH Industrial N.V., Amsterdam, the Netherlands). Spring-sown barley (cv. Wolmari, fourrowed, Boreal Plant Breeding Ltd., Jokioinen, Finland) and spring-sown triticale (cv. Nagano, Berner Ltd., Helsinki, Finland) were used as whole crop silages. The sowing rates of barley and triticale growths were 220 and $200 \mathrm{~kg}$ ha $^{-1}$ and sowing dates were 8 and 13 June 2017, respectively. Both BS and TS were harvested at the soft dough stage (growth stage Z85; Zadoks et al. 1974) of the cereal using a direct-cut flail harvester (Claas Jaguar 970, Claas Group, Harsewinkel, Germany) and at a stubble height of about $10 \mathrm{~cm}$. The harvest date of both whole crop silages was 19 September 2017. All three silages were treated with a formic acid-based additive (GrasAAT SX, Addcon Group $\mathrm{GmbH}$, Bitterfeld-Wolfen, Germany) applied at a rate of $5 \mathrm{It}^{-1}$ of fresh forage and stored in bunker silos.

\section{Feed sampling and analysis}

During the feeding experiment silage sub-samples were taken twice a week, pooled over periods of four weeks and stored at $-20^{\circ} \mathrm{C}$ prior to analyses. Thawed samples were analyzed for DM, ash, crude protein (CP), neutral detergent fibre (NDF) assayed with a heat stable amylase and expressed exclusive of residual ash, indigestible NDF (iNDF), ether extract, starch, silage fermentation quality $(\mathrm{pH}$, water-soluble carbohydrates [WSC], lactic and formic acids, ethanol, volatile fatty acids [VFA] and ammonia N content of total N), and digestible organic matter (DOM) in DM (DOMD, D-value). Barley and rapeseed meal sub-samples were collected weekly, pooled over periods of eight weeks and analyzed for DM, ash, CP, NDF, ether extract and starch.

The DM concentration was determined by drying at $105^{\circ} \mathrm{C}$ for $20 \mathrm{~h}$. Samples for chemical analyses were dried at $60^{\circ} \mathrm{C}$ for $16 \mathrm{~h}$ and milled using sample mill (Sakomylly KT-3100, Koneteollisuus Ltd., Helsinki, Finland) with a $1 \mathrm{~mm}$ sieve. Oven DM concentration of silages was corrected for the loss of volatiles according to Huida et al. (1986). The ash concentration was determined by ashing at $600{ }^{\circ} \mathrm{C}$ for $2 \mathrm{~h}$. Nitrogen $(\mathrm{N})$ content was determined by the Dumas method (AOAC method 968.06; AOAC 1990) using a Leco FP 428 nitrogen analyzer (Leco, St Joseph, MI, USA). Crude protein content was calculated as $6.25 \times \mathrm{N}$ content. Concentration of NDF was determined according to Van Soest, et al. (1991) using Na-sulphite and presented ash-free. Ether extract was analyzed according to the official method 920.39 (AOAC 1990), starch according to Salo and Salmi (1968), and iNDF as described by Huuskonen et al. (2008). The measurement of DOMD of silages was based on the in vitro pepsin-cellulase method (Friedel 1990) with modifications described by Nousiainen et al. (2003). Organic matter digestibility of the silages was calculated using a correction equation which converts pepsin-cellulase solubility values into in vivo digestibility. The forage-specific equations are based on a data set comprising of Finnish in vivo digestibility trials (Huhtanen et al. 2006). Fresh silage samples were analyzed for fermentation characteristics by electrometric titration as described by Moisio and Heikonen (1989).

The metabolizable energy (ME) concentration of GS was calculated as ME $\left(\mathrm{MJ} \mathrm{kg} \mathrm{kg}^{-1} \mathrm{DM}\right)=16.0 \times \mathrm{DOMD}\left(\mathrm{kg} \mathrm{kg}^{-1}\right.$ DM) (MAFF 1984). For whole crop silages, a coefficient of 15.5 instead of 16.0 was used (MAFF 1984). The ME concentration of concentrate feeds was calculated based on the tabulated digestibility coefficients and analyzed chemical composition, except for crude fibre concentrations tabulated values were used (Luke 2020). In the Scandinavian feed protein evaluation system (Madsen et al. 1995), the protein value of the diet is expressed as amino absorbed from the small intestine (metabolizable protein, MP) and the protein balance value in the rumen (PBV), which describes the balance between the dietary supply of rumen-degradable protein (RDP) and the microbial requirements for RDP. In the present study MP and PBV were calculated using the Finnish version (Tuori et al. 1998, Luke 2020) of the Scandinavian feed protein evaluation system. The relative intake potential of silage DM (SDMI index) was calculated as described by Huhtanen et al. (2007). 


\section{AGRICULTURAL AND FOOD SCIENCE}

A. Huuskonen et al. (2020) 29: 318-330

\section{Live weight and carcass measurements}

The bulls were weighed on two consecutive days at the beginning of the experiment and thereafter approximately every 28 days. Before slaughter they were weighed on two consecutive days. The target for the average carcass weight was $370 \mathrm{~kg}$ and $410 \mathrm{~kg}$ for HF and CH bulls, respectively, which are near the average carcass weights for slaughtered HF and CH bulls in Finland (Pesonen and Huuskonen 2015). The bulls were selected for slaughter based on LW and assumed dressing proportions (530 and $560 \mathrm{~g} \mathrm{~kg}^{-1}$ for HF and CH bulls, respectively) which were assessed based on earlier studies (Pesonen et al. 2013a) in Finland with beef breed bulls. The LW gain (LWG) was calculated as the difference between the means of the initial and final LW divided by the number of growing days. The estimated rate of carcass gain was calculated as the difference between the final carcass weight and the carcass weight at the beginning of the experiment divided by the number of growing days. The carcass weight at the start of the experiment was assumed to be $0.52 \times$ initial LW based on earlier studies (unpublished data).

The bulls were slaughtered in the Atria Ltd. commercial slaughterhouse in Kauhajoki, Finland in three batches. All five feeding treatments were represented in all batches (6-7 bulls per feeding treatment in all batches). After slaughter the carcasses were weighed hot. The cold carcass weight was estimated as 0.98 of the hot carcass weight. Dressing proportions were calculated from the ratio of cold carcass weight to final LW. The carcasses were graded for conformation and fatness using the EUROP quality classification (EC 2006).

\section{Statistical methods}

The results are shown as least squares means. The data were subjected to analysis of variance using the SAS GLM procedure (version 9.4, SAS Institute Inc., Cary, NC, USA). The statistical model used was

$y_{i j k l m}=\mu+\delta_{k}+\alpha_{i}+\gamma_{j}+(\alpha \times \gamma)_{i j}+\theta_{i j m}+\beta x_{i j k l}+e_{i j k l m}$

where $\mu$ is the intercept and $e_{i j k l m}$ is the residual error term associated with $\mathrm{I}^{\text {th }}$ animal. $\alpha_{i}, \gamma_{\mathrm{j}}$ and $(\alpha \times \gamma)_{\mathrm{ij}}$ are the effects of $i^{\text {th }}$ diet (GS, TS, GSTS, BS, GSBS) and $j^{\text {th }}$ breed $(H F, C H)$ and their interaction, respectively, while $\delta_{k}$ is the effect of the slaughtering batch $(1,2,3)$ and $\theta_{\mathrm{ijm}}$ is the effect of pen. The effect of pen was used as an error term when differences between treatments (diet, breed and their interaction) were compared because treatments were allocated to animals penned together. Initial LW was used as a covariate $\left(\beta \mathrm{x}_{\mathrm{ijk}}\right)$ in the model.

Differences between the treatments were tested using orthogonal contrasts: (1) breed (HF vs. CH); (2) TMRs containing whole crop silage (TS, GSTS, BS, GSBS) vs. GS; (3) triticale (TS, GSTS) vs. barley (BS, GSBS); (4) mixtures (GSTS, GSBS) vs. pure whole crop rations (TS, BS); (5) interaction between contrasts 3 and 4 (whether the GS inclusion has a different effect with TS and BS); (6) interaction between contrasts 1 and 2; (7) interaction between contrasts 1 and 3 ; (8) interaction between contrasts 1 and 4 ; and (9) interaction between contrasts 1 and 5 . As there were only a few significant $(p<0.05)$ interactions between breed and feeding treatments, the $p$-values of these interactions are not presented in tables.

\section{Results \\ Feeds}

Chemical composition and feeding values of the experimental feeds are available in Table 2. Due to the weather conditions during harvesting, the DM concentration of GS was 35 and $41 \%$ lower compared to TS and BS, respectively. According to feed analyses, the GS had 51 and $49 \%$ higher CP concentrations as well as 13 and $39 \%$ higher NDF content compared to TS and BS. Furthermore, the GS had 15 and $8 \%$ higher ME concentration as well as 13 and 7\% higher MP concentration compared to TS and BS, respectively. The BS included 79\% more starch compared to TS. Moreover, BS had $26 \%$ and TS $17 \%$ higher SDMI index than GS (Table 2). The barley grain and rapeseed meal had typical chemical compositions and feeding values, corresponding to the average values in the Finnish Feed Tables (Luke 2020). 


\section{AGRICULTURAL AND FOOD SCIENCE}

A. Huuskonen et al. (2020) 29: 318-330

Table 2. Chemical compositions and feeding values (mean \pm standard deviation) of the experimental feeds and calculated chemical compositions and feeding values of the total mixed rations used in the feeding experiment

\begin{tabular}{|c|c|c|c|c|c|c|c|c|c|c|c|}
\hline & \multicolumn{6}{|c|}{ Feeds } & \multicolumn{5}{|c|}{ Total mixed rations } \\
\hline & GS & TS & BS & Barley & RSM & MM & GS & TS & GSTS & BS & GSBS \\
\hline Number of feed samples & 6 & 6 & 6 & 3 & 2 & 2 & & & & & \\
\hline Dry matter (DM), $\mathrm{g} \mathrm{kg}^{-1}$ & $205 \pm 19.7$ & $314 \pm 22.2$ & $350 \pm 24.5$ & $872 \pm 9.8$ & $876 \pm 1.1$ & $986 \pm 1.0$ & 295 & 422 & 348 & 460 & 360 \\
\hline $\begin{array}{l}\text { Organic matter (OM), } \\
\mathrm{g} \mathrm{kg}^{-1} \mathrm{DM}\end{array}$ & $931 \pm 2.3$ & $949 \pm 3.6$ & $946 \pm 3.6$ & $977 \pm 0.4$ & $924 \pm 0.8$ & $65 \pm 0.5$ & 932 & 943 & 938 & 941 & 937 \\
\hline Crude protein, $\mathrm{g} \mathrm{kg}^{-1} \mathrm{DM}$ & $148 \pm 23.3$ & $98 \pm 14.3$ & $99 \pm 9.7$ & $105 \pm 5.3$ & $377 \pm 3.8$ & $9 \pm 0.1$ & 143 & 113 & 128 & 113 & 128 \\
\hline $\begin{array}{l}\text { Neutral detergent fibre } \\
\text { (NDF), } \mathrm{g} \mathrm{kg}^{-1} \mathrm{DM}\end{array}$ & $559 \pm 23.8$ & $496 \pm 28.4$ & $402 \pm 27.2$ & $213 \pm 28.5$ & $284 \pm 11.0$ & $25 \pm 0.5$ & 421 & 383 & 402 & 327 & 374 \\
\hline $\begin{array}{l}\text { Indigestible NDF, } \\
\mathrm{g} \mathrm{kg}^{-1} \mathrm{DM}\end{array}$ & $64 \pm 26.48$ & $146 \pm 13.56$ & $116 \pm 7.81$ & ND & ND & ND & & & & & \\
\hline Starch, $\mathrm{g} \mathrm{kg}^{-1} \mathrm{DM}$ & $6 \pm 1.5$ & $172 \pm 16.0$ & $308 \pm 27.7$ & $569 \pm 23.7$ & $13 \pm 0.1$ & $7 \pm 0.1$ & 195 & 294 & 245 & 376 & 285 \\
\hline Ether extracts, $\mathrm{g} \mathrm{kg}^{-1} \mathrm{DM}$ & $38 \pm 5.5$ & $21 \pm 1.0$ & $22 \pm 2.0$ & $17 \pm 3.0$ & $29 \pm 0.7$ & $6 \pm 0.1$ & 30 & 20 & 25 & 21 & 25 \\
\hline $\begin{array}{l}\text { Metabolizable energy, } \\
\text { MJ kg-1 DM }\end{array}$ & $11.0 \pm 0.46$ & $9.6 \pm 0.15$ & $10.2 \pm 0.16$ & $13.2 \pm 0.06$ & $11.4 \pm 0.01$ & $5.0 \pm 0.1$ & 11.6 & 10.8 & 11.2 & 11.1 & 11.3 \\
\hline $\begin{array}{l}\text { Metabolizable protein, } \\
\mathrm{g} \mathrm{kg}^{-1} \mathrm{DM}\end{array}$ & $88 \pm 6.15$ & $78 \pm 2.80$ & $82 \pm 1.50$ & $95 \pm 1.53$ & $169 \pm 1.45$ & $5 \pm 0.2$ & 93 & 87 & 90 & 89 & 91 \\
\hline $\begin{array}{l}\text { Protein balance in the } \\
\text { rumen, } \mathrm{g} \mathrm{kg}^{-1} \mathrm{DM}\end{array}$ & $19 \pm 17.01$ & $-17 \pm 9.87$ & $-22 \pm 4.82$ & $-38 \pm 10.60$ & $154 \pm 2.45$ & $1 \pm 0.1$ & 6 & -15 & -4 & -18 & -6 \\
\hline $\begin{array}{l}\text { Digestible OM in DM, } \\
\mathrm{g} \mathrm{kg}^{-1} \mathrm{DM}\end{array}$ & $685 \pm 28.9$ & $622 \pm 9.4$ & $659 \pm 10.3$ & ND & ND & ND & & & & & \\
\hline Silage DM intake index & $98 \pm 7.47$ & $115 \pm 4.37$ & $123 \pm 1.21$ & & & & & & & & \\
\hline \multicolumn{12}{|l|}{$\begin{array}{l}\text { Fermentation quality of } \\
\text { silages }\end{array}$} \\
\hline $\mathrm{pH}$ & $3.72 \pm 0.03$ & $3.91 \pm 0.05$ & $3.90 \pm 0.06$ & & & & & & & & \\
\hline $\begin{array}{l}\text { Volatile fatty acids, } \\
\mathrm{g} \mathrm{kg}^{-1} \mathrm{DM}\end{array}$ & $17 \pm 2.10$ & $9 \pm 2.42$ & $10 \pm 4.03$ & & & & & & & & \\
\hline $\begin{array}{l}\text { Lactic + formic acid, } \\
\mathrm{g} \mathrm{kg}^{-1} \mathrm{DM}\end{array}$ & $68 \pm 6.22$ & $31 \pm 3.37$ & $39 \pm 8.41$ & & & & & & & & \\
\hline $\begin{array}{l}\text { Water soluble } \\
\text { carbohydrates, } \mathrm{g} \mathrm{kg}^{-1} \mathrm{DM}\end{array}$ & $53 \pm 41.48$ & $116 \pm 14.06$ & $60 \pm 9.46$ & & & & & & & & \\
\hline $\mathrm{NH}_{4} \mathrm{~N}$ in total $\mathrm{N}, \mathrm{g} \mathrm{kg}^{-1}$ & $50 \pm 5.87$ & $54 \pm 2.99$ & $26 \pm 10.76$ & & & & & & & & \\
\hline
\end{tabular}

The fermentation characteristics of all three silages were good, as indicated by low concentrations of ammonia $\mathrm{N}$ in total $\mathrm{N}$ and low total fermentation acids (Table 2). All silages were restrictively fermented with high residual WSC concentration and relatively low lactic acid concentration. However, the WSC concentration of TS was clearly higher compared to GS and BS.

Due to the differences in chemical composition and feeding values of the silages, TMR composition differed among the treatments (Table 2). Replacing whole crop silages partially or completely by GS reduced the DM and starch content but increased CP, NDF and ME concentration of TMR.

\section{Feed and nutrient intake}

The feeding experiment lasted 160 days and the slaughter age of the bulls was 470 days, on average (Table 3). No significant interactions for the slaughter age or final LW were observed. There was no difference in slaughter age between the breeds but the bulls fed TMRs containing whole crop silage were slightly younger at slaughter compared to the bulls fed GS $(p<0.05)$. The final LW of the $\mathrm{CH}$ bulls was $5 \%$ higher $(p<0.001)$ compared to the HF bulls, but there were no differences among feeding treatments in final LW. 


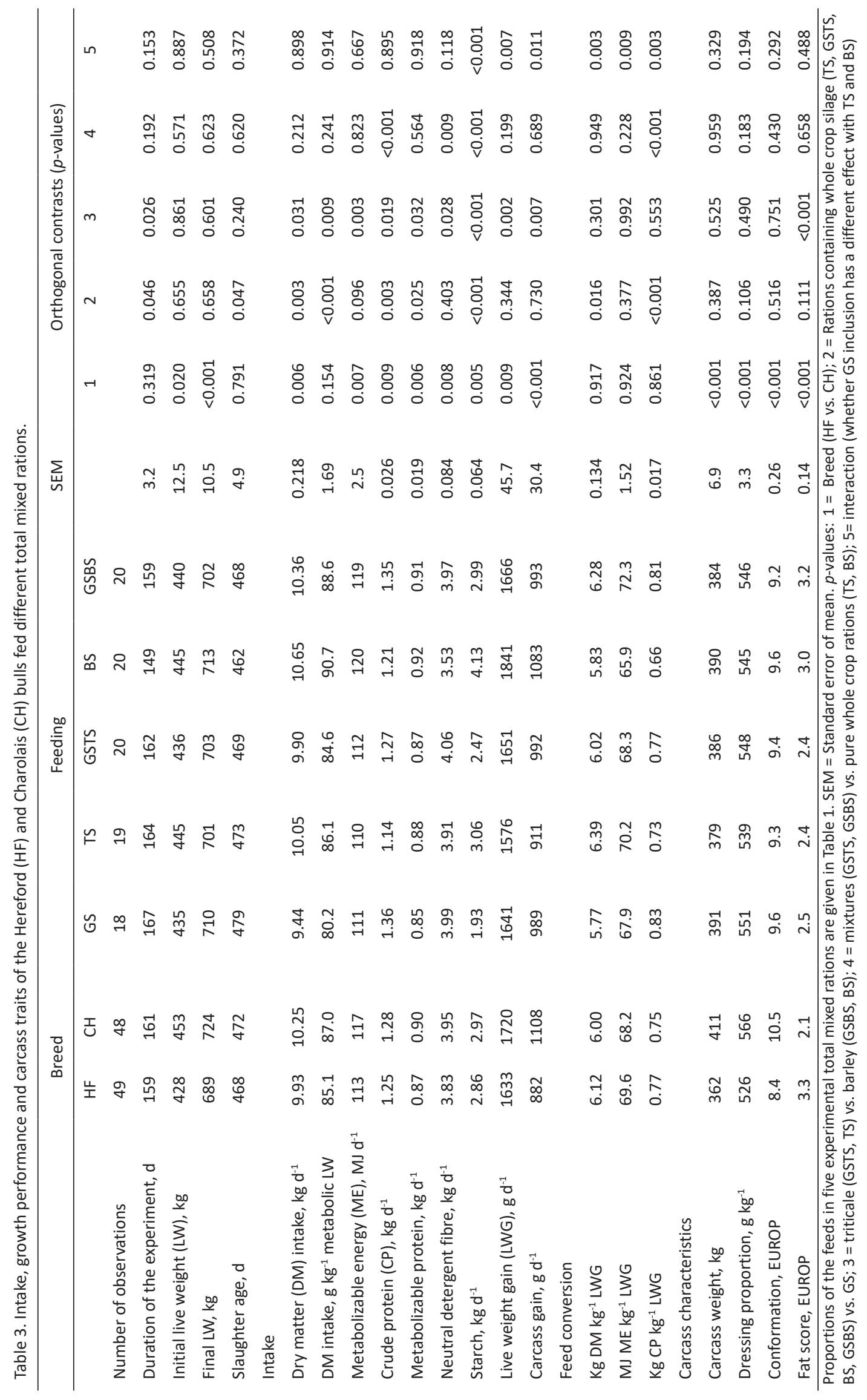


For DM, ME, MP, starch and NDF intake significant breed $\times$ feeding interactions were observed. In CH bulls, DMI decreased $0.8 \mathrm{~kg} \mathrm{~d}^{-1}$ when GS partly replaced whole crop silage (TS or BS) while in HF bulls the use of silage mixtures slightly increased DMI $\left(0.23 \mathrm{~kg} \mathrm{~d}^{-1}\right)$ (interaction $p<0.05$; breed $\times$ contrast 4$)$ (Fig. 1). The differences in DMI resulted in similar types of changes in ME and MP intakes (interaction $p<0.05$; breed $\times$ contrast 4 ). Instead, the differences between whole crop silage and silage mixtures in starch and NDF were partly unrelated to the changes in DMI (interaction $p<0.05$; breed $\times$ contrast 4) (Fig. 1).
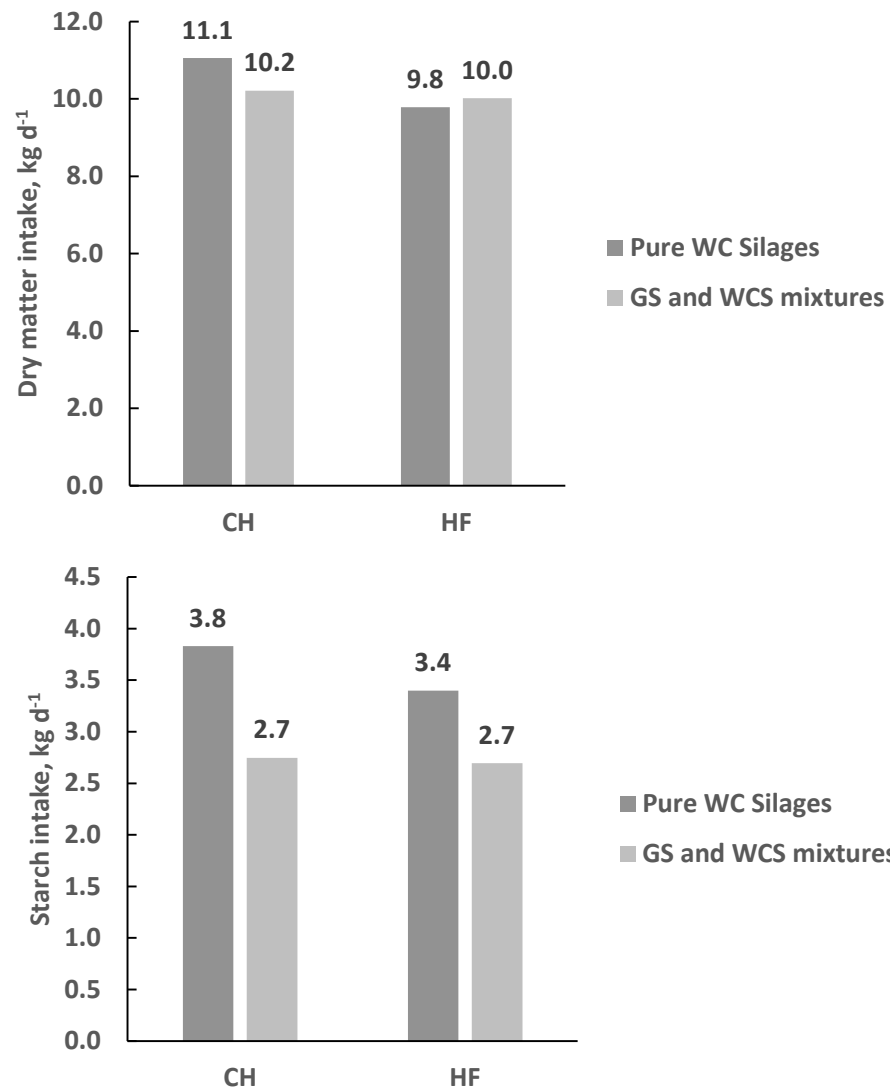

$$
\begin{aligned}
& \text { Pure WC Silages } \\
& \text { GS and WCS mixtures }
\end{aligned}
$$

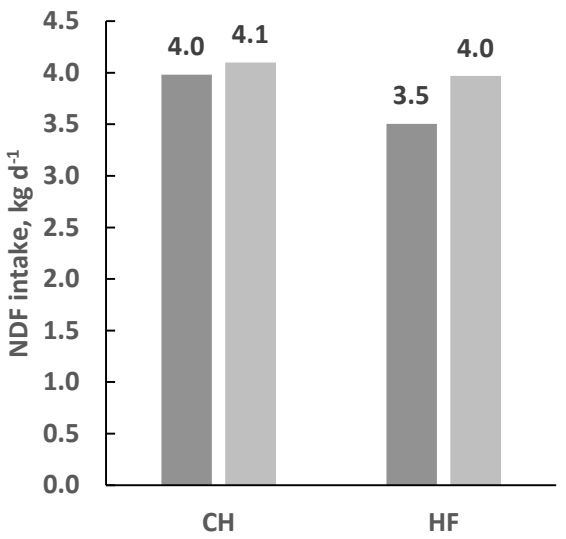

Pure WC Silages

GS and WCS mixtures

Fig. 1. Differences between Charolais $(\mathrm{CH})$ and Hereford (HF) in intake responses to the partial replacement of whole crop (WC) silages (WCS) (triticale or barley) with grass silage (GS) in total mixture rations (interaction $p<0.05$; breed $\times$ contrast 4). Dry matter intake; $S E M=0.22$, starch intake; $S E M=0.06$, and neutral detergent fibre (NDF) intake; SEM $=0.08$.

Whole crop silage containing diets increased clearly both total daily DMI and daily DMI per metabolic LW (DMI ${ }_{\text {met }}$ ) when compared to GS diet $(p<0.01)$ (Table 3$)$. The bulls receiving whole crop silages had higher MP and starch intake compared to the GS bulls while ME intake tended to increase $(p<0.1)$ and CP intake decreased $(p<0.001)$. 
Compared to the TS based rations the use of BS rations increased both daily DMI $(p<0.05)$ and $\mathrm{DMI}_{\text {met }}(p=0.01)$ by $5 \%$, on average (Table 3). In addition, ME, CP and MP intake increased and NDF intake decreased when BS was included in the ratio instead of TS.

\section{Growth performance, feed conversion and carcass characteristics}

Inclusion of GS in the diet increased LWG 5\% and carcass gain 9\% with TS but decreased them 10 and $8 \%$, respectively, with BS (interaction $p<0.01$ ). There were also significant interactions in feed conversion as DM and energy conversion rates were poorer with BS but improved with TS when GS replaced partially whole crop silages. No significant breed $\times$ feeding interactions for LWG, carcass gain or feed conversion were observed.

The LWG and carcass gain of the $\mathrm{CH}$ bulls were 5 and $26 \%$ higher, respectively, compared to the HF bulls but there was no difference in feed conversion between the breeds (Table 3). Feed conversion ratio ( $\mathrm{kg} \mathrm{DM} \mathrm{kg}^{-1} \mathrm{LWG}_{\text {) for }}$ whole crop silage diets was poorer than that for GS diet $(p<0.05)$ but the use of whole crop silages improved protein conversion rate ( $\left.\mathrm{g} \mathrm{CP} \mathrm{kg}{ }^{-1} \mathrm{LWG}\right)(p<0.001)$ compared to GS diet (Table 3).

For dressing proportion a significant breed $\times$ feeding interaction was observed. Partial replacement of TS with GS increased dressing proportion from 554 to $574 \mathrm{~g} \mathrm{~kg}^{-1}$ in $\mathrm{CH}$ bulls while a slightly lower dressing proportion was observed due to GS inclusion in BS diet. In HF bulls, no effect was observed in dressing proportion when GS replaced part of TS, but a small increase was observed with BS diet (interaction $p<0.05$; breed $\times$ contrast 5) (Fig. 2). No significant interactions for the carcass weight, carcass conformation or carcass fat score were observed.

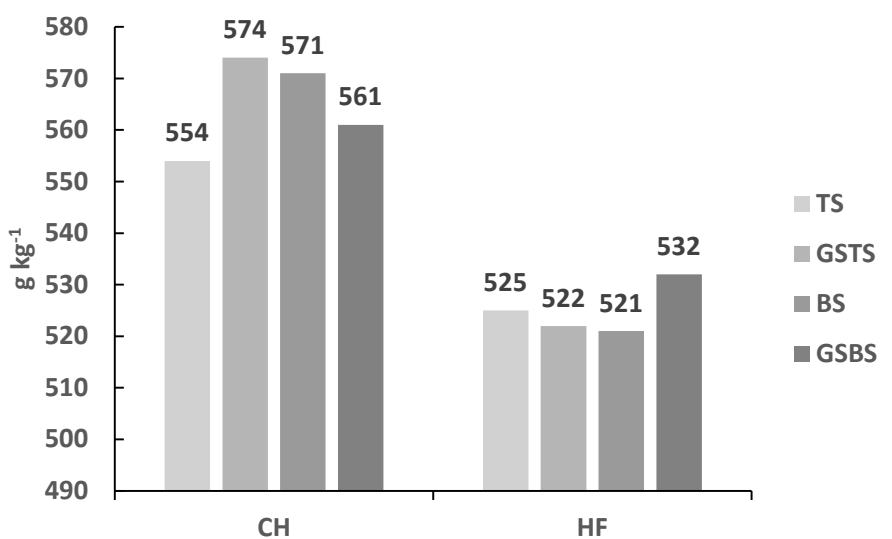

Fig. 2. Differences between Charolais (CH) and Hereford (HF) in dressing proportion $\left(\mathrm{g} \mathrm{kg}^{-1}\right.$ ) response to the partial replacement of triticale silage (TS) or barley silage (BS) with grass silage (GS) in total mixture rations (interaction $p<0.05$; breed $\times$ contrast 5$)(S E M=3.3)$

The carcass weight and carcass conformation score of the $\mathrm{CH}$ bulls were 14 and $25 \%$ higher $(p<0.001)$, respectively, than the corresponding values of the HF bulls (Table 3). In addition, the carcass fat score of the HF bulls was $57 \%$ higher compared to the $\mathrm{CH}$ bulls. There were no significant differences in carcass weight or carcass conformation score among the feeding treatments (Table 3). However, compared to the TS based rations the use of BS increased carcass fat score $(p<0.001)$.

\section{Discussion \\ Effects of breed}

In the present study, DMI of the $\mathrm{CH}$ bulls decreased when GS partly replaced whole crop silage while in HF bulls the use of silage mixtures slightly increased DMI compared to whole crop silages as a sole forage. Reason for this effect is not clear. Previously, Jardstedt et al. (2018) hypothesised that DMI in these breeds might differ due to their evolutionary backgrounds since $\mathrm{HF}$ and $\mathrm{CH}$ breeds have been historically developed on low- and high-quality forage diets, respectively. However, in their feeding experiment with pregnant beef cows DMI appeared to be related to the different LW of these two breeds, as the breed difference in DMI was no longer present when intake 


\section{AGRICULTURAL AND FOOD SCIENCE}

A. Huuskonen et al. (2020) 29: 318-330

was related to LW, suggesting that intake was similarly constrained in both breeds (Jardstedt et al. 2018). In the present experiment, $\mathrm{CH}$ bulls were able to eat more TS and BS diets containing low-digestible whole crop silage but higher content of starch compared to GSTS and GSBS diets containing more digestible GS.

In agreement with the present results, Continental breeds have been observed to be superior in growth performance and carcass conformation compared to British breeds in several experiments, and the higher growth capacity and better conformed carcasses of the $\mathrm{CH}$ breed compared to $\mathrm{HF}$ breed has been demonstrated previously in numerous studies (e.g. Krupa et al. 2005, Bartoň et al. 2006, Pesonen et al. 2013a,b, Pesonen and Huuskonen 2015). The lower dressing proportion of the HF bulls can be partly explained by lower average carcass weight compared to the $\mathrm{CH}$ bulls because it is established that the dressing proportion is increased by increasing slaughter weight (Kempster et al. 1988). However, the body composition and dressing proportion of beef breeds is not dependent only on carcass weight. For example, Bartoň et al. (2006) reported that at the same carcass weight end point the dressing proportion for $\mathrm{CH}$ was $2.3 \%$ higher than that of HF. It is well established that earlier maturing British beef breeds produce relatively more fat than later maturing Continental breeds in spite they would be slaughtered at a significantly lower LW (Bartoň et al. 2006, Pesonen et al. 2013a,b, Pesonen and Huuskonen 2015). The higher fat deposition of HF compared to $\mathrm{CH}$ was clearly demonstrated also in the present experiment.

\section{Effects of feeding treatments}

At harvesting, both TS and BS were assessed to be at the soft dough stage by following kernel development according to Zadoks growth scale (Zadoks et al. 1974). However, TS had higher NDF, and iNDF contents but lower DOMD and starch contents compared to BS. These differences suggest that TS was harvested at earlier growth stage than BS. Givens et al. (1993) suggested that the assessment of growth stage alone may not be a good guide to the composition and digestibility of whole crop cereal silages. Thus, the nutritive values of triticale and barley at the same soft dough stage might have been different, possibly due to higher proportion of straw in triticale than in barley (not measured).

The observed differences in the carbohydrate concentration of the whole crop silages harvested at the dough stage agrees with the results reported earlier in the Nordic countries (e.g. Nadeau 2007, Jaakkola et al. 2009, Wallsten et al. 2009). For example, Nadeau (2007) observed that barley had more starch whereas triticale had more sugar at the same stage of maturity. Nevertheless, the comparison of different experiments is challenging since the deposition of sugar to starch depends on many factors like plant varieties, location as well as weather and growing conditions. In field experiments carried out previously in Finland the WSC content was lowest in barley cultivars and highest in triticale although all crops were harvested at the early dough stage (Lötjönen and Huuskonen 2018).

In line with previous studies (Sinclair et al. 2003, O'Kiely 2011, Huuskonen 2013) the digestibility (in vitro) of the whole crop silages was lower than that of the GS. In general, the digestibility of whole crop cereals is highly dependent on the straw and grain proportions and varies considerably between studies (Sinclair et al. 2003). Raising the cutting height reduces the proportion of the straw in the harvested material and typically increases digestibility as well as starch and CP concentrations of whole crop silages (O'Kiely 2011). However, in the present study both BS and TS were harvested at a same stubble height of about $10 \mathrm{~cm}$.

The CP concentration of whole crop silages is commonly lower than that of moderately digestible GS (O'Kiely 2011, Huuskonen 2013, Huuskonen et al. 2017) as observed in the present study. The Finnish recommendation for growing cattle above $200 \mathrm{~kg} \mathrm{LW}$ is that diet PBV should be above $-10 \mathrm{~g} \mathrm{~kg}^{-1} \mathrm{DM}$ which ensures sufficient nitrogen supply for the needs of rumen microbes (Luke 2020). This was fulfilled in GS, GSTS and GSBS rations. In TS and $B S$ rations, the PBV value was slightly lower than recommended. However, based on the meta-analysis of the growing cattle feeding experiments, Huuskonen et al. (2014) concluded that recommended PBV could be even lower than the current $-10 \mathrm{~g} \mathrm{~kg}^{-1} \mathrm{DM}$ without harmful effects on animal performance. Huuskonen et al. (2014) found that there was no relationship between dietary CP concentration on the control diet (the lowest CP) and LWG response to protein supplementation suggesting that the RDP requirements were met by all diets or that N recycling compensated for the limited supply from the control diet. Earlier, Marini and Van Amburgh (2003) observed that the amount of $\mathrm{N}$ recycled into the gastrointestinal tract was $27 \mathrm{~g} \mathrm{~kg}^{-1} \mathrm{DMI}$ in cattle fed low CP ( $80 \mathrm{~g}$ $\mathrm{kg}^{-1} \mathrm{DM}$ ) diet. Advantages of using MP in estimating protein supply and requirements are questionable at least for growing cattle above $200 \mathrm{~kg}$ LW. In meta-analyses, small LWG responses to feed MP indicated that microbial protein and rumen-undegraded protein from high quality forages and energy supplements met the protein requirements when growing cattle are fed GS or whole crop silage based diets supplemented with grain (Huuskonen et al. 2014, Huuskonen and Huhtanen 2015). 


\section{AGRICULTURAL AND FOOD SCIENCE}

A. Huuskonen et al. (2020) 29: 318-330

It is observed that animals have often been able to maintain or even increase DMI after inclusion of whole crop silage into the diet, although its digestibility has been lower than that of GS (Ahvenjärvi et al. 2006, Huuskonen 2013, Keady et al. 2013). This effect could be explained by the lower NDF concentration in whole crop silages compared to GS (Huhtanen et al. 2007) and by changes in passage and digestion kinetics of cell walls (Ahvenjärvi et al. 2006). In the present experiment the lower digestibility and ME content of the whole crop silages was compensated by higher DMI as hypothesized. This could have been due to differences in NDF content and digestion kinetics but can also be partly explained by differences in DM content and lower amount of total fermentation acids in whole crop silages compared to GS. The products of silage in-silo fermentation generally depress DMI (Wright et al. 2000, Huhtanen et al. 2007, Huuskonen et al. 2013). Based on the meta-analysis, Huuskonen et al. (2013) reported that both the extent and type of fermentation influenced silage DMI in growing cattle. Increased extent of in-silo fermentation decreased DMI with the adverse effect being greater for VFA, especially propionic acid, than for lactic acid (Huuskonen et al. 2013). Due to the weather conditions during harvesting, the DM concentration of GS was clearly lower compared to TS and BS explaining partly the lower DMI of the GS bulls compared to the whole crop silage based diets. Many earlier data evaluations have reported positive association between silage DM concentration and DMI (Steen et al. 1998, Wright et al. 2000, Huhtanen et al. 2007). A meta-analysis by Huhtanen et al. (2007) implied that silage DMI is independently affected by its DM concentration. In growing cattle Steen et al. (1998) reported that the maximum GS intake was achieved at a DM concentration of $320 \mathrm{~g} \mathrm{~kg}^{-1} \mathrm{while}$ in dairy cows Huhtanen et al. (2007) observed that the maximum silage DMI was predicted at a DM concentration of $419 \mathrm{~g} \mathrm{~kg}^{-1}$.In the present study, the DMI was greater on BS diets (BS and GSBS) compared to TS diets (TS and GSTS) which was probably partly due to the lower NDF and iNDF concentrations and higher in vitro OM digestibility of BS compared to TS.

One explanation for treatment differences in growth performance could be differences in DMI and nutrient intakes. Based on the meta-analysis, Huuskonen and Huhtanen (2015) found that energy intake was clearly the most important variable affecting LWG of growing cattle whereas the results showed only marginal effects of protein supply on growth. The results of the present experiment support this because the highest LWG was achieved at the highest ME intake level. Previously, Huuskonen and Joki-Tokola (2010) observed that ME intake and growth rate of dairy bulls was higher with GS based diet compared to whole crop wheat based diet, but BS based diet did not differ from the GS diet. Some earlier studies have reported that the inclusion of whole crop wheat in GS based diets decreased (O'Kiely and Moloney 1999), had no effect (Keady et al. 2007) or increased (Walsh et al. 2008) gain of finishing cattle. Walsh et al. (2008) observed clearly lower growth performance when growing steers were fed GS based diet instead of a whole crop wheat silage-based diet. However, GS in the study by Walsh et al. (2008) had a relatively low nutritive value due to advanced maturity of the crop, wet weather at harvesting and relatively poor preservation quality.

The present results are consistent with McCartney and Vaage (1994) who compared TS and BS in beef heifers and concluded that the lower gain of heifers given TS appeared to be primarily related to a reduced DMI. In that study of McCartney and Vaage (1994), TS had higher DM (416 vs. $313 \mathrm{~g} \mathrm{~kg}^{-1}$ ) and NDF (540 vs. $513 \mathrm{~g} \mathrm{~kg}^{-1} \mathrm{DM}$ ) content and lower apparent DM digestibility (digestibility coefficients in sheep 0.588 vs. 0.642 ) compared to BS. On the other hand, ZoBell et al. (1992) observed that TS and BS produced similar intake and gain when fed to feedlot steers. ZoBell et al. (1992) reported that there was very little difference between TS and BS for nutrient content although CP concentration was 1.5\% higher for TS. Distinctions between the observations in separate experiments can be due to differences in forage:concentrate rations used. In the study of ZoBell et al. (1992), silages were fed at lower levels (258-380 $\left.\mathrm{g} \mathrm{kg}^{-1} \mathrm{DM}\right)$ than in McCartney and Vaage (1994) (850-870 $\mathrm{g} \mathrm{kg}^{-1} \mathrm{DM}$ ) or in the present experiment (600 g kg-1 DM). Overall, the comparison of different experiments is challenging since the nutritive values and growth responses of whole crop silages differ largely depending on the stage of maturity of the plants at harvest, cutting height, plant species and variety, growing and harvesting conditions as well as harvesting and storage techniques, which all affect the chemical composition, preservation quality and relative proportions of grain and straw (Rustas 2009, Wallsten et al. 2009, O’Kiely 2011, Keady et al. 2013, Huuskonen et al. 2016).

Consistent with the present experiment, O'Kiely (2011) reported poorer feed conversion ratio for TS diets compared GS diet and Huuskonen (2013) observed poorer feed conversion for BS compared to GS diet. In the present study, protein conversion efficiency declined when GS replaced whole crop silages and the observed effect was lower with TS than with BS. The relatively low protein content of whole crop silages can be seen as an environmental advantage. Recent results of Huhtanen and Huuskonen (2020) indicate that decreasing dietary N inputs in growing cattle diet would be an effective way to decrease urinary and manure $\mathrm{N}$ output, and to reduce excretions per kg LWG and carcass gain. Major proportion of incremental $\mathrm{N}$ intake is excreted in urine and urinary $\mathrm{N}$ is more susceptible to both leaching and evaporation compared to faecal N (Huhtanen and Huuskonen 2020). 
In accordance with previous experiments (Keady et al. 2007, Huuskonen and Joki-Tokola 2010, O'Kiely 2011), carcass conformation was not affected when whole crop silages was replaced by GS. Based on the meta-analysis of data from growing cattle, Huuskonen and Huhtanen (2015) found that increased ME intake improved carcass conformation. However, this was not observed in the present experiment. The use of BS increased carcass fat score compared to the TS based rations which could be due to increased ME intake. It is well documented that increased energy intake of growing cattle often increases carcass fatness (Huuskonen et al. 2007, Pesonen et al. 2013a, Huuskonen and Huhtanen 2015, Manni et al. 2016).

\section{Conclusions}

The later maturing $\mathrm{CH}$ bulls seemed to reach higher carcass weights and produce better conformed carcasses and less fat compared to the earlier maturing HF bulls. According to our hypothesis, the use of whole crop silages increased DMI of the growing and finishing bulls compared to low DM GS as a sole forage source in the total mixed ration. Furthermore, the present experiment demonstrated lower feeding value of whole crop TS compared to whole crop BS in the diet of the bulls. Replacing TS partly by low DM GS increased LWG and carcass gain and improved feed DM conversion while on BS diet GS inclusion decreased gains and impaired feed conversion. The results indicate that the benefits of using mixtures of whole crop and grass silages rather than sole whole crop silage depends on the various characteristics of silages used.

\section{Acknowledgments}

This study was partially funded by the Centre for Economic Development, Transport and the Environment for Northern Ostrobothnia, Oulu, Finland, Eastman Chemical Company, Berner Ltd and Hankkija Ltd. We wish to express our gratitude to Mr. Jarkko Kekkonen and his personnel for their technical assistance and care of the experimental animals. The authors thank Mr. Lauri Jauhiainen for advice on statistical analysis.

\section{References}

Ahvenjärvi, S., Joki-Tokola, E., Vanhatalo, A., Jaakkola, S. \& Huhtanen, P. 2006. Effects of replacing grass silage with barley silage in dairy cow diets. Journal of Dairy Science 89: 1678-1687. https://doi.org/10.3168/jds.S0022-0302(06)72235-4

AOAC 1990. Official Methods of Analysis. Association of Official Analytical Chemists, Inc. Arlington, Virginia, USA. 1298 p.

Bartoň, L., Řehák, D., Teslík, V., Bureš, D. \& Zahrádková, R. 2006. Effect of breed on growth performance and carcass composition of Aberdeen Angus, Charolais, Hereford and Simmental bulls. Czech Journal of Animal Science 51: 47-53. https://doi.org/10.17221/3908-CJAS

EC 2006. Council Regulation (EC) No 1183/2006 of 24 July 2006 concerning the Community scale for the classification of carcasses of adult bovine animals. The Official Journal of the European Union L214: 1-6.

Friedel, K. 1990. Die Schätzung des energetischen Futterwertes von Grobfutter mit Hilfe einer Cellulasemethode. [The estimation of the energetic feeding value of roughages by means of a cellulase method]. Wissenschaftliche Zeitschrift Universitet Rostock, N-Reihe 39: 78-86.

Givens, D.I., Moss, A. R. \& Adamson, A. H. 1993. The digestion and energy value of whole crop wheat treated with urea. Animal Feed Science and Technology 43: 51-64. https://doi.org/10.1016/0377-8401(93)90142-7

Harper, M.T., Oh, J., Giallongo, F., Roth, G.W. \& Hristov, A.N. 2017. Inclusion of wheat and triticale silage in the diet of lactating dairy cows. Journal of Dairy Science 100: 6151-6163. https://doi.org/10.3168/jds.2017-12553

Hill, G.M \& Utley, P.R. 1989. Digestibility, protein metabolism and ruminal degradation of Beagle 82 triticale and Kline barley fed in corn-based diets. Journal of Animal Science 67: 1793-1804. https://doi.org/10.2527/jas1989.6771793x

Huhtanen, P. \& Huuskonen, A. 2020. Modelling effects of carcass weight, dietary concentrate and protein levels on the $\mathrm{CH}_{4}$ emission, N and P excretion of dairy bulls. Livestock Science 232: 103896. https://doi.org/10.1016/j.livsci.2019.103896

Huhtanen, P., Nousiainen, J. \& Rinne, M. 2006. Recent developments in forage evaluation with special reference to practical applications. Agricultural and Food Science 15: 293-323.https://doi.org/10.2137/145960606779216317.

Huhtanen, P., Rinne, M. \& Nousiainen, J. 2007. Evaluation of the factors affecting silage intake of dairy cows; a revision of the relative silage dry matter intake index. Animal 1: 758-770. https://doi.org/10.1017/S175173110773673X

Huida, L., Väätäinen, H. \& Lampila, M. 1986. Comparison of dry matter contents in grass silage as determined by oven drying and gas chromatographic water analysis. Annales Agriculturae Fenniae 25: 215-230.

Huuskonen, A. 2013. Performance of growing and finishing dairy bulls offered diets based on whole-crop barley silage with or without protein supplementation relative to a grass silage-based diet. Agricultural and Food Science 22: 424-434. https://doi.org/10.23986/afsci.8558

Huuskonen, A. \& Huhtanen, P. 2015. The development of a model to predict BW gain of growing cattle fed grass silage-based diets. Animal 9: 1329-1340. https://doi.org/10.1017/S1751731115000610 


\section{AGRICULTURAL AND FOOD SCIENCE}

A. Huuskonen et al. (2020) 29: 318-330

Huuskonen, A., Huhtanen, P. \& Joki-Tokola, E. 2013. The development of a model to predict feed intake by growing cattle. Livestock Science 158: 74-83. https://doi.org/10.1016/j.livsci.2013.10.005

Huuskonen, A., Huhtanen P. \& Joki-Tokola, E. 2014. Evaluation of protein supplementation for growing cattle fed grass silage-based diets: a meta-analysis. Animal 8: 1653-1662. https://doi.org/10.1017/S1751731114001517

Huuskonen, A. \& Joki-Tokola, E. 2010. Performance of growing dairy bulls offered diets based on silages made of whole-crop barley, whole-crop wheat, hairy vetch and grass. Agricultural and Food Science 19: 116-126. https://doi.org/10.2137/145960610791542325

Huuskonen, A., Khalili, H. \& Joki-Tokola, E. 2007. Effects of replacing different proportions of barley grain by barley fibre on performance of dairy bulls. Agricultural and Food Science 16: 232-244. https://doi.org/10.2137/145960607783328227

Huuskonen, A., Khalili, H. \& Joki-Tokola, E. 2008. Inclusion of barley fibre and barley protein in a total mixed ration for growing dairy bulls. Acta Agriculturae Scandinavica, Section A, Animal Science 58: 37-44. https://doi.org/10.1080/09064700802029842

Huuskonen, A., Pesonen, M. \& Honkavaara, M. 2016. Performance and meat quality of Nordic Red and Aberdeen Angus bulls offered faba bean or field pea based whole crop legume-cereal silages. Agricultural and Food Science 25: 1-12. https://doi.org/10.23986/afsci.52311

Huuskonen, A., Pesonen, M. \& Joki-Tokola, E. 2017. Feed intake and live weight gain of Hereford bulls offered diets based on whole-crop barley and whole-crop wheat silages relative to moderate digestible grass silage with or without protein supplementation. Annals of Animal Science 17: 1123-1134. https://doi.org/10.1515/aoas-2017-0007

Jaakkola, S., Saarisalo, E. \& Heikkilä, T. 2009. Formic acid treated whole crop barley and wheat silages in dairy cow diets: effects of crop maturity, proportion in the diet, and level and type of concentrate supplementation. Agricultural and Food Science 18: 234-256. https://doi.org/10.2137/145960609790059569

Jardstedt, M., Hessle, A., Nørgaard, P., Frendberg, L. \& Nadeau, E. 2018. Intake and feed utilization in two breeds of pregnant beef cows fed forages with high-fiber concentrations. Journal of Animal Science 96: 3398-3411. https://doi.org/10.1093/jas/sky199

Keady, T.W.J. 2005. Ensiled maize and whole crop wheat forages for beef and dairy cattle: effects on animal performance. In: Park, R.S. \& Stronge, M.D. (eds.). Silage production and utilization technology. Proceedings of the XIVth International Silage Conference, Belfast, Northern Ireland. p. 65-82.

Keady, T.W.J., Hanrahan, J.P., Marley, C.L. \& Scollan, N.D. 2013. Production and utilization of ensiled forages by beef cattle, dairy cows, pregnant ewes and finishing lambs: a review. Agricultural and Food Science 22: 70-92. https://doi.org/10.23986/afsci.6852

Keady, T.W., Lively, F.O., Kilpatrick, D.J. \& Moss, B.W. 2007. Effects of replacing grass silage with either maize or whole-crop wheat silages on the performance and meat quality of beef cattle offered two levels of concentrates. Animal 1: 613-623. https://doi.org/10.1017/S1751731107685024

Kempster, A.J., Cook, G.L. \& Southgate, J.R. 1988. Evaluation of British Friesian, Canadian Holstein and beef breed $\times$ British Friesian steers slaughtered over commercial range of fatness from 16-month and 24-month beef production systems. 2 . Carcass characteristics, and rate and efficiency of lean gain. Animal Production 46: 365-378. https://doi.org/10.1017/S0003356100018973

Krupa, E., Oravcova, M., Polak, P., Huba, J. \& Krupova, Z. 2005. Factors affecting growth traits of beef cattle breeds raised in Slovakia. Czech Journal Animal Science 50: 14-21. https://doi.org/10.17221/3990-CJAS

Lötjönen, T. \& Huuskonen, A. 2018. Triticale, barley and wheat as a raw material of whole-crop silage. In: NJF Congress: Agriculture for the next 100 years, Nordic Association of Agricultural Scientists, Kaunas, Lithuania: p. 26

Luke 2020. Feed Tables and Nutrient Requirements. Natural Resources Institute Finland (Luke), Helsinki, Finland. http://www. luke.fi/feedtables (cited 31 January 2020)

Madsen, J., Hvelplund, T., Weisbjerg, M.R., Bertilsson, J., Olsson, I., Spörndly, R., Harstad, O.M., Volden, H., Tuori, M., Varvikko, T., Huhtanen, P. \& Olafsson, B.L. 1995. The AAT/PBV protein evaluation system for ruminants. A revision. Norwegian Journal of Agricultural Science, Supplement 19: 1-37.

MAFF 1984. Energy Allowances and Feeding Systems for Ruminants. ADAS Reference book 433. Ministry of Agriculture, Fisheries and Food. Her Majesty's Stationery Office, London. 85 p.

Manni, K., Rinne, M. \& Huuskonen, A. 2016. Effects of barley intake and allocation regime on performance of growing dairy bulls offered highly digestible grass silage. Livestock Science 191: 72-79. https://doi.org/10.1016/j.livsci.2016.07.004

Marini, J.C. \& Van Amburgh, M.E. 2003. Nitrogen metabolism and recycling in Holstein heifers. Journal Animal Science 81: 545552. https://doi.org/10.2527/2003.812545x

McCartney, D.H. \& Vaage, A.S. 1994. Comparative yield and feeding value of barley, oat and triticale silages. Canadian Journal Animal Science 74: 91-96. https://doi.org/10.4141/cjas94-014

Moisio, T. \& Heikonen, M. 1989. A titration method for silage assessment. Animal Feed Science and Technology 22: $341-353$. https://doi.org/10.1016/0377-8401(89)90078-3

Nadeau, E. 2007. Effects of plant species, stage of maturity and additive on the feeding value of whole-crop cereal silage. Journa of the Science of Food and Agriculture 87: 789-801. https://doi.org/10.1002/jsfa.2773

Nousiainen, J., Rinne, M., Hellämäki, M. \& Huhtanen, P. 2003. Prediction of the digestibility of the primary growth of grass silages harvested at different stages of maturity from chemical composition and pepsin-cellulase solubility. Animal Feed Science and Technology 103: 97-111. https://doi.org/10.1016/S0377-8401(03)00206-2

O'Kiely, P. 2011. Intake, growth and feed conversion efficiency of finishing beef cattle offered diets based on triticale, maize or grass silages, or ad libitum concentrate. Irish Journal of Agricultural and Food Research 50: 189-207. https://doi.org/10.2307/41549251.

O'Kiely, P. \& Moloney, A.P. 1999. Whole crop wheat silage for finishing beef heifers. Irish Journal of Agriculture and Food Research 38: 296. (Abstract). 


\section{AGRICULTURAL AND FOOD SCIENCE}

A. Huuskonen et al. (2020) 29: 318-330

Peltonen-Sainio, P., Jauhiainen, L., Hakala, K. \& Ojanen, H. 2009. Climate change and prolongation of growing season: changes in regional potential for field crop production in Finland. Agricultural and Food Science 18: 171-190. https://doi.org/10.2137/145960609790059479

Pesonen, M., Honkavaara, M. \& Huuskonen, A. 2013b. Production, carcass and meat quality traits of Hereford, Charolais and Hereford $\times$ Charolais bulls offered grass silage-grain-based rations and slaughtered at high carcass weights. Acta Agriculturae Scandinavica, Section A, Animal Science 63: 28-38. https://doi.org/10.1080/09064702.2013.777091

Pesonen, M., Honkavaara, M., Kämäräinen, H., Tolonen, T., Jaakkola, M., Virtanen, V. \& Huuskonen, A. 2013a. Effects of concentrate level and rapeseed meal supplementation on performance, carcass characteristics, meat quality and valuable cuts of Hereford and Charolais bulls offered grass silage-barley-based rations. Agricultural and Food Science 22: 151-167. https://doi.org/10.23986/afsci.6703

Pesonen, M. \& Huuskonen, A. 2015. Production, carcass characteristics and valuable cuts of beef breed bulls and heifers in Finnish beef cattle population. Agricultural and Food Science 24: 164-172. https://doi.org/10.23986/afsci.50930

Pesonen, M., Joki-Tokola, E. \& Huuskonen, A. 2014. The effect of silage plant species, concentrate proportion and sugar beet pulp supplementation on the performance of growing and finishing crossbred bulls. Animal Production Science 54: 1703-1708. https://doi.org/10.1071/AN14141

Rustas, B.-O. 2009. Whole-crop cereals for growing cattle. Effects of maturity stage and chopping on intake and utilisation. Doctoral Thesis. Swedish University of Agricultural Sciences, Skara, Sweden. 60 p.

Salo, M-L. \& Salmi, M. 1968. Determination of starch by the amyloglucosidase method. Jounal of the Scientific Agricultural Society of Finland 40: 38-45.https://doi.org/10.23986/afsci.71697

Sinclair, L.A., Wilkinson, R.G. \& Ferguson, D.M.R. 2003. Effects of crop maturity and cutting height on the nutritive value of fermented whole crop wheat and milk production in dairy cows. Livestock Production Science 81: 257-269. https://doi.org/10.1016/S0301-6226(02)00261-0

Steen, R.W.J., Gordon, F.J., Dawson, L.E.R., Park, R.S., Mayne, C.S., Agnew, R.E., Kilpatrick, D.J. \& Porter, M.G. 1998. Factors affecting the intake of grass silage by cattle and prediction of silage intake. Animal Science 66: 115-127. https://doi.org/10.1017/S1357729800008894

Tuori, M., Kaustell, K.V. \& Huhtanen, P. 1998. Comparison of the protein evaluation systems of feeds for dairy cows. Livestock Production Science 55: 33-46. https://doi.org/10.1016/S0301-6226(98)00126-2

Van Soest, P.J., Robertson, J.B. \& Lewis, B.A. 1991. Methods for dietary fiber, neutral detergent fiber, and nonstarch polysaccharides in relation to animal nutrition. Journal of Dairy Science 74: 3583-3597. https://doi.org/10.3168/jds.S0022-0302(91)78551-2

Wallsten, J., Nadeau, E., Bertilsson, B. \& Martinsson, K. 2009. Voluntary intake and diet selection by dairy heifers fed ensiled whole-crop barley and oats harvested at different stages of maturity. Livestock Science 122: 94-98. https://doi.org/10.1016/j.livsci.2008.07.031

Walsh, K., O'Kiely, P., Moloney, A.P. \& Boland, T.M. 2008. Intake, performance and carcass characteristics of beef cattle offered diets based on whole-crop wheat or forage maize relative to grass silage or ad libitum concentrates. Livestock Science 116: 223236. https://doi.org/10.1016/j.livsci.2007.10.010

Wright, D.A., Gordon, F.J., Steen, R.W.J. \& Patterson, D.C. 2000. Factors influencing the response in intake of silage and animal performance after wilting of grass before ensiling: a review. Grass and Forage Science 55: 1-13. https://doi.org/10.1046/j.1365-2494.2000.00198.x

Zadoks, J.C., Chang, T.T. \& Konzak, C.F. 1974. A decimal code for the growth stages of cereals. Weed Research 14: 415-421. https://doi.org/10.1111/j.1365-3180.1974.tb01084.x

ZoBell, D.R., Goonewardene, L.A. \& Engstrom, D.F. 1990. Potential of triticale as a feed for finishing heifers. Canadian Journal of Animal Science 70: 325-328. https://doi.org/10.4141/cjas90-040

ZoBell, D.R., Goonewardene, L.A. \& Engstrom, D.F. 1992. Use of triticale silage in diets for growing steers. Canadian Journal of Animal Science 72: 181-184. https://doi.org/10.4141/cjas92-023 